\title{
AN AIR-DRYING METHOD FOR FIRST MEIOTIC PROPHASE PREPARATIONS FROM MAMMALIAN OVARIES
}

\author{
J. M. LUGIANI, MONIQUE DEVICTOR-VUILLET, \\ R. GAGNÉ AND A. STAHL \\ Laboratoire d'Histologie et Embryologie, \\ Faculté de Médecine, Université de Marseille, France*
}

(Received 16th Fuly 1973)

Recent studies on meiosis in male germinal cells have been able to provide data on all meiotic stages since it is now easier to obtain preparations of good quality, notably by the air-drying method introduced by Evans, Breckon \& Ford (1964). Squash procedures applied to mammalian testicular material, though successful in demonstrating most stages of meiosis, do not always yield enough well-spread figures for detailed examination (for critical review, see Luciani, Capodano-Vagner \& Devictor-Vuillet, 1972).

Only conventional squash methods have been used for the study of meiosis in fetal ovaries (Ohno, Klinger \& Atkin, 1962; Baker, 1963; Kindred, 1963; Manotaya \& Potter, 1963).

This paper presents a simple quick method for successful demonstration of all the stages of first meiotic prophase in a number of female fetal or neonatal mammals, including human, rabbit and cat.

One ovary is removed and placed in isotonic salt solution, such as Hanks or TC 199. The contents of the ovary are obtained by scraping with the curved blade of a lancet under a dissecting microscope and by teasing out the largest fragments with two fine straight forceps. The fragments are allowed to settle; the supernatant fluid is then transferred to a 15-ml centrifuge tube and treated in the same manner as the cell suspensions obtained from testicular specimens (Luciani, Devictor-Vuillet \& Stahl, 1971), but without hypotonic treatment and acid hydrolysis.

This method has given excellent results for human fetal oocytes, but has proved unsatisfactory to obtain good preparations from the ovaries of neonatal cat and rabbit. It was difficult to release the germinal cells from the ovaries by the usual fragmentation process. The technique was, therefore, modified by adding $45 \%$ glacial acetic acid which caused the ovarian fragments to become rapidly transparent as the germinal cells fell into suspension. This property of acetic acid to dissociate the cells was used by Meredith (1969) to obtain meiotic chromosomes from mammalian testes.

The final procedure which gave the best results from all the types of ovaries examined, including also ovaries from chick and quail embryos, may therefore be summarized as follows.

\footnotetext{
* Postal address: 27, Bd. J. Moulin, 13385 Marseille Cedex 4.
} 
Immediately after removal, the ovary is placed either in isotonic salt solution or preferably in fixative (methanol/glacial acetic acid $=3 / 1 \mathrm{v} / \mathrm{v}$ ) and is then cut into minute pieces. The cell suspension and fragments obtained are separately treated.

(1) All the fragments are transferred to a conical vial. The excess of fixative is removed and about ten drops of freshly prepared $45 \%$ glacial acetic acid are added and thoroughly mixed. After 3 or $4 \mathrm{~min}$, the germinal cells fall into suspension. This suspension is taken up into a small pipette and droplets are transferred to pre-cooled, wet slides. The quality of the cellular spreading is controlled using a phase-contrast microscope and the procedure is repeated four or five times.

(2) The cell suspension is centrifuged at $800 \mathrm{rev} / \mathrm{min}$ for $8 \mathrm{~min}$. The supernatant is removed and the pellet is resuspended in a few drops of freshly prepared $45 \%$ glacial acetic acid. The suspension is thoroughly mixed and pipetted. Droplets are transferred either to pre-cooled slides or to dry slides. In the latter case, it is necessary to add some droplets of methanol to the final suspension to ensure good spreading.

Finally, the preparations are stained with Giemsa solution or with some other chromatin stain.

Preparations obtained by this method are illustrated in Plates 1 and 2, Figs 1 to 8.

Apart from the ease and speed of handling, the main interest from the procedure lies in the isolation of individual cells so that they are evenly dispersed over the slides.

Hypotonic treatment is not prejudicial to the quality of the figures. For preparations from spermatocytes, $\mathrm{KCl}$ solution at $0.30 \mathrm{mg} / 100 \mathrm{ml}$ can be used (Luciani et al., 1971), but we have rarely used such hypotonic treatment in studies involving oocytes since the method yields no morphological details and disappearance of nucleoli makes it impossible to study nucleolar-chromosomal relationships.

Although the preparations untreated with $45 \%$ glacial acetic acid were aesthetically more pleasing, those in which some of the fibres were partly disrupted by acetic acid solution usually provided one or more important structural details that were not as readily appreciated in the more completely preserved specimens. There was also much less breakage than with squash techniques. Use of $45 \%$ glacial acetic acid solution appears to be necessary not only when fragmentation is difficult, but also in order to reveal the sites of heterochromatic segments, as has already been demonstrated in spermatocytes (Gagné, Vagner-Capodano \& Devictor-Vuillet, 1973).

The results obtained by this technique have led us to identify a preleptotene chromosome contraction stage in human fetal oocytes (Stahl \& Luciani, 1971) and more recently in rabbit oocytes (Devictor-Vuillet, Luciani \& Stahl, 1973). The relationships between nucleoli and chromosomes during the meiotic prophase of the human fetal oocyte have been also described (Stahl \& Luciani, 1972).

Supported by C.N.R.S., Equipe de recherche associée No. 397, except for R.G. who holds a grant from the Quebec Medical Research Council, Canada. 

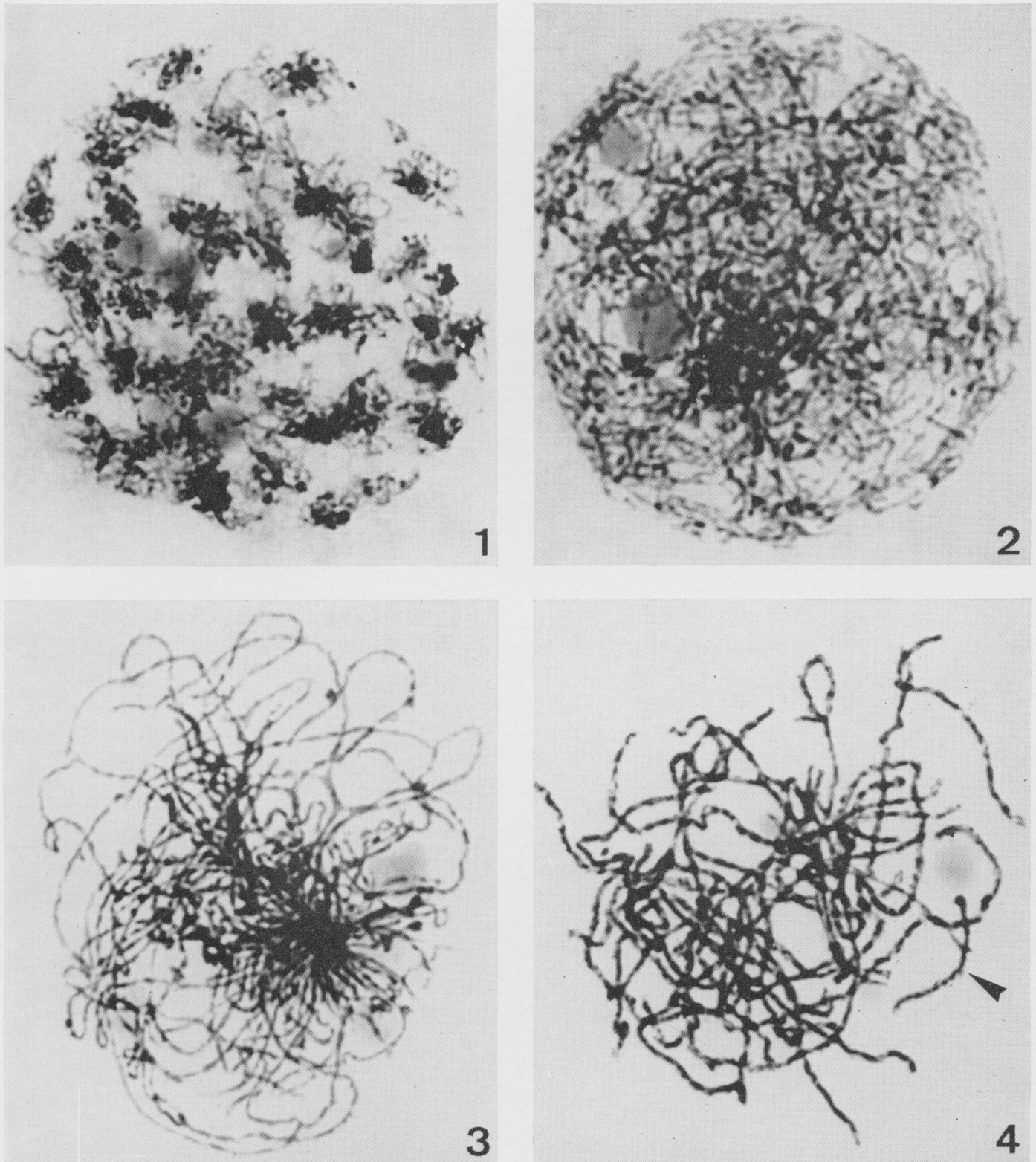

Frgs 1 to 4. Ovary fragmentation in TC 199 medium. Fixation: methanol/glacial acetic acid $(3 / 1)$. Fragments treated with $45 \%$ acetic acid, except for Fig. 3. Giemsa stain.

FIG. 1. Human preleptotene nucleus showing chromosomal contraction in the despiralization phase. Note the appearance of fine threads extending from the 46 'prochromosomes' and their relations with nucleolar material. $\times 1600$.

Fig. 2. Human leptotene nucleus. $\times 2200$.

Fig. 3. Human lepto-zygotene nucleus. $\times 1400$.

Fig. 4. Human pachytene nucleus showing an acrocentric chromosomal-nucleolar association (arrow). $\times 1600$. 
PLATE 2

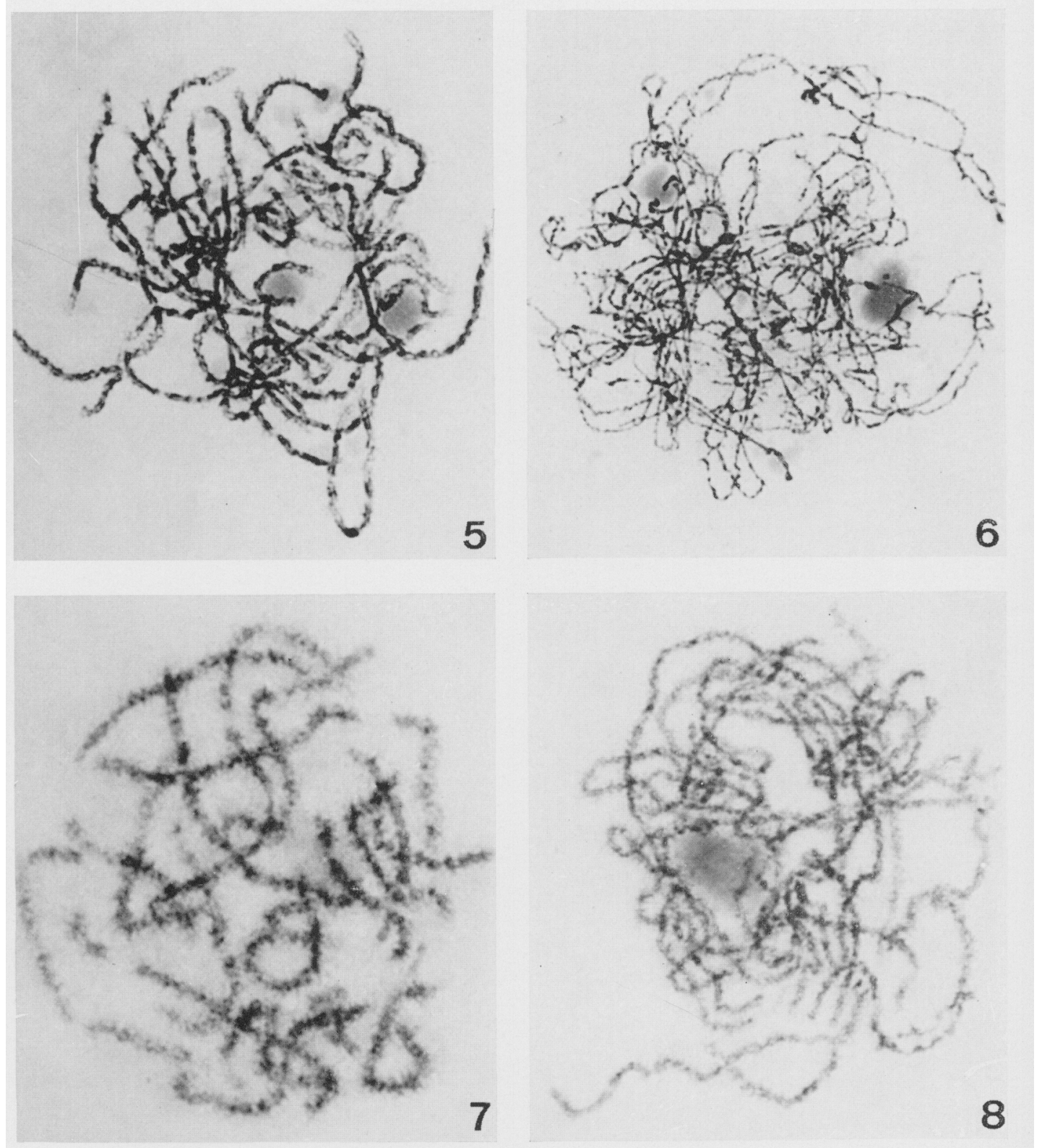

FIG. 6. The same technique as that described for Pl. 1, Figs 1, 2 and 4.

Figs 5,7 and 8 . Ovary fragmentation in fixative. Treatment of the fragments with $45 \%$ acetic acid. Giemsa stain.

Fig. 5. Human pachytene nucleus. $\times 1600$.

Fig. 6. Human diplotene nucleus. $\times 1200$.

FIG. 7. Rabbit pachytene nucleus. $\times 1600$.

Fig. 8. Cat pachytene nucleus. $\times 1600$. 


\section{REFERENGES}

Baker, T. G. (1963) A quantitative and cytological study of germ cells in human ovaries. Proc. R. Soc. B, 158, 417.

Devictor-Vuillet, M., Luciani, J. M. \& Stahl, A. (1973) Individualisation d'un stade préleptotène de condensation chromosomique dans l'ovocyte de la lapine. C.r. hebd. Séanc. Acad. Sci., Paris, 276, 2453.

Evans, E. P., Breckon, G. \& Ford, G. E. (1964) An air-drying method for meiotic preparations from mammalian testes. Cytogenetics, 3, 289.

Gagné, R., Vagner-Capodano, A. M. \& Devictor-Vuillet, M. (1973) Intérêt de la localisation de l'hétérochromatine pour l'identification des chromosomes méiotiques à la diacinèse chez l'Homme. C.r. hebd. Séanc. Acad. Sci., Paris, 276, 769.

KindRed, J. E. (1963) The chromosomes of the ovary of the human fetus. Anat. Rec., 147, 295.

Luciani, J. M., Gapodano-Vagner, A. M. \& Devictor-Vuillet, M. (1972) Techniques d'analyse de la meiose chez l'Homme. In: Biologie Génétique, pp. 41-53. Monogr. ann. Soc. Fr. Biol. Clin., l'Expansion Edn., Paris.

Luciani, J. M., Devictor-Vuillet, M. \& Stahl, A. (1971) Hypotonic KGi : an improved method of processing human testicular tissue for meiotic chromosomes. Clin. Genet. 2, 32.

Manotaya, T. \& Potrer, E.L. (1963) Oocytes in prophase of meiosis from squash preparations of human fetal ovaries. Fert. Steril. 14, 378.

Meredith, R. (1969) A simple method for preparing meiotic chromosomes from mammalian testis. Chromosoma, 26, 254.

Ohno, S., Klinger, H. P. \& Atrin, N. B. (1962) Human oögenesis. Cytogenetics, 1, 42.

Stahl, A. \& Luciani, J. M. (1971) Individualisation d'un stade preleptotène de condensation chromosomique au début de la méiose chez l'ovocyte foetal humain. C.r. hebd. Séanc. Acad. Sci., Paris, $272,2041$.

Stahl, A. \& Luciani, J. M. (1972) Nucleoli and chromosomes: their relationships during the meiotic prophase of the human fetal oocyte. Humangenetik, 14, 269. 